\title{
Discursive Institutionalism as Framework of Analysis for Multi-Vector Power Relations in Organizing Political Parties
}

\author{
Wawan Edi Kuswandoro', Kacung Marijan², Kris Nugroho² \\ ${ }^{1}$ Doctorate Program of Social Science, Faculty of Social and Political Sciences, Airlangga University, Surabaya, Indonesia \\ ${ }^{2}$ Department of Political Science, Faculty of Social and Political Sciences, Airlangga University, Surabaya, Indonesia \\ Email: wawan.edi.kuswandoro-2014@fisip.unair.ac.id
}

How to cite this paper: Kuswandoro, W. E., Marijan, K., \& Nugroho, K. (2020). Discursive Institutionalism as Framework of Analysis for Multi-Vector Power Relations in Organizing Political Parties. Open Journal of Political Science, 10, 607-625. https://doi.org/10.4236/ojps.2020.104036

Received: July 8, 2020

Accepted: August 15, 2020

Published: August 18, 2020

Copyright $\odot 2020$ by author(s) and Scientific Research Publishing Inc. This work is licensed under the Creative Commons Attribution International License (CC BY 4.0).

http://creativecommons.org/licenses/by/4.0/

\begin{abstract}
This article investigates power relations in Intra-Party Democracy in the study of organizing political parties. Intra-Party Democracy refers to the notion of formal political institutions, whereas the political process more often occurs informally, personally, multi-vector which involves multi actors, multi political resources and power relations no longer come from formal institutional sources but any direction and beyond the reach of formal institutions. Using the literature review method, this article enhances the explanation of Intra-Party Democracy by presenting the perspective of Discursive Institutionalism as an analytical framework that bridges multi-vector power relations that occur in organizing political parties. Discursive Institutionalism explores the actors' discursive capabilities, namely coordinative discourse and communicative discourse in the discursive process in organizing political parties.
\end{abstract}

\section{Keywords}

Discursive Institutionalism, Political Party, Power Relations, Intra-Party Democracy

\section{Introduction}

This article investigates the power relations between political actors in organizing political parties using the theory of Intra-Party Democracy. The study of political parties organizing in new democracies was based on Katz-Mair's thought on parties in government, the relationship between parties with institutions and the public (Katz, Mair et al., 2008; Katz \& Mair, 1994, 1995; Mair et al., 2020; Webb \& White, 2008), focusing on the way of political parties organize them- 
selves to build electoral power (Scarrow et al., 2017). In a study of organizing political parties, Intra-Party Democracy represents a competition between elites in the pursuit of power (von dem Berge \& Poguntke, 2017), including relations between actors in organizational aspects such as leadership changes, political recruitment, and party policy formulation (Scarrow et al., 2017). Intra-Party Democracy requires a party leader to engage in external relations, external coordination, reach out to social elements, and party leaders need internal support for these functions to smooth the hold public office effort such as building coalition (Lehrer, 2016). Trends in political personalization (Calise, 2015; Dalton et al., 2003; Emanuele et al., 2015; Emanuele \& Marino, 2016; Garzia, 2013; Meeks, 2017; Rahat \& Hazan, 2013; Shin, 2017; Tan, 2006) in Intra-Party Democracy has shifted the political process from party institutions to interpersonal (Rahat \& Hazan, 2013). This fact further opens up a more fluid, multi-space institutional discourse of political parties (Susewind, 2020), and requires a perspective that further explains micro-subjective relations that describe relations between actors (Serpa \& Ferreira, 2019). This explanation at the micro-subjective level has not been accommodated by Intra-Party Democracy.

The theoretical problem that arises is how Intra-Party Democracy accommodates the relational explanation among actors in the body of the party with the role of multi-actors, multi-directions, and multi-resources. This article aims to provide theoretical elaboration to increase the explanation of Intra-Party Democracy on power relations among actors with a micro-subjective approach. For this reason, the article offers a model of Discursive Institutionalism developed from Schmidt's thought (Carstensen \& Schmidt, 2016; Larsson, 2015; Schmidt, 2008, 2017b; Schmidt, 2010; Schmidt, 2012; Van Gorp et al., 2011) which highlights the role of actors, personal, in line with Intra-Party Democracy which has shifted to the role of personal politics (Calise, 2015; Emanuele \& Marino, 2016; Mikola, 2017; Rahat \& Hazan, 2013). The perspective of Discursive Institutionalism uses the communicative power discourse approach (Schmidt, 2008, 2017b), to elaborate multi-vector intra-party democracy, which involves multi-actor, multi-political, multi-directional resources related to social base functions that contain norms, regulations, policies and social practices (Hurlbert \& Gupta, 2019). Discursive Institutionalism combines the concepts of new institutionalism based on actor roles combined with Foucault's power discourse (Armstrong, 2015; Guizzo \& de Lima, 2015; Hofvenschioeld \& Khodadadi, 2020) and Habermas' communicative power (Habermas, J translated by Regh W, 1996) which gave rise to the ability of actor's discursive towards institutions through the process of interaction of ideas and power in political parties.

\section{Method}

This article uses a literature review as a research method, to find certain issues, mapping and study as well as finding accuracy in certain theories and related theories (Snyder, 2019), verifying theories or, constructing new theories (Lan- 
guage et al., 2018). A literature review is carried out systematically on specific topics (Burgers et al., 2019) with a focus on research concepts and results published by scientific journals (Hutzschenreuter et al., 2020) to find gaps of these theories for the development of new methods (Gentles et al., 2016). A literature review for this article is carried out on international journal articles until mapping of theorization is found in the study of organizing political parties so that gaps can be found in these theories. It is at this gap that a new perspective is offered which has not yet emerged on the tradition of organizing political parties.

The literature review research method is run in several steps. First, find the development of the theory of organizing political parties by examining papers in numbers of international journals, outlined in the literature review section. Second, find theories commonly used to explain the internal dynamics of organizing political parties. Third, make a synthesis of step one and step two dragged as a conclusion. Fourth, from this conclusion, theoretical problems are drawn which are the theoretical gap of organizing political parties using the Intra-Party Democracy theory. Fifth, based on the central issue, a check is made of the key elements in the focus being investigated, namely power relations in Intra-Party Democracy. Sixth, find the key elements that are the problem and develop them in the discovery of new theories and methods as an explanatory problem, namely Discursive Institutionalism.

\section{Literature Reviews}

\subsection{Organizing Political Parties}

The theoretical development of political parties organizing in new democracies is related to the understanding of institutions in Huntington's conception, namely the procedures, internal rules of political parties (Huntington \& Fukuyama, 2006). The development of the theory of organizing political parties is inseparable from the conception of the organization of the Katz-Mair formulation of party organizations about parties in grassroots, parties in public offices and parties in central offices (Katz, Mair et al., 2008), which in its organizational aspect, political parties in Western democracies are based on the ideas of Lipset \& Rokkan and Duverger (Poguntke, 2002). Lipset \& Rokkan's thought laying the foundation of political party theory on a social basis of social cleavage as a result of social segregation from social heterogeneity (Torcal \& Mainwaring, 2003). This reasoning states that the organization of political parties cannot be separated from their association with the social basis of social division in society as the main supporting element. Whereas Duverger looks at political parties linked to the electoral system and voter behavior (Janda \& Colman, 1998).

The theories of organizing political parties are developed from the assumption of a dialectical process of reflection, that is, one type of party produces another new type of party, and so on as the Gunther-Diamond and Katz-Mair formulations. The dialectics of party organizations, according to Gunther-Diamond, are not only derived from changes in civil society which are the source of the forma- 
tion of elite-based parties, mass-based parties, electoral parties, ethnicity-based parties, and movement parties (Gunther \& Diamond, 2003) but also changes in relations between parties and the state, especially relations that are getting closer between parties and the state, which ultimately results in a new type of party, the cartel parties (Katz \& Mair, 1995; Vernardakis, 2012). Based on this classification, Gunther-Diamond believes that the party is associated with forms of clients in the community, such as mass organizations and social groups or certain masses. Electoral parties in the view of Gunther-Diamond consist of personal parties, programmatic parties and catch-all parties that associated with all types of social groups (Gunther \& Diamond, 2003). Meanwhile, Janda and Colman review the organization of political parties from the complexity of the procedures used by the party to coordinate the activities of party supporters, the centralization of the policy determination process, the extent to which party members and sympathizers are involved in efforts to achieve party objectives, and factionalization within the party body (Janda \& Colman, 1998). The organization of political parties discusses the institutional performance of political parties, as Randall \& Svåsand argued, that organization of political parties was conceptualized in four institutional dimensions, namely systematic, decisional autonomy, value infusion, and reification (Randall \& Svåsand, 2002). Webb \& White linked a political party's institutional performance with electoral activity (Webb \& White, 2007). After Randall \& Svåsand and Webb \& White, the discussion of organizing political parties more focussed on political party institutions that involve the role of political resources influenced them, for example, institutional strength, individual influences, and factors of political institutions. As found in the writings of Sampugnaro, Rangel, and Scarrow-Webb, the discussion of political parties' relations had a great deal to their relationship with individuals, internal democratic procedures and communities, groups, and networks outside the parties (Sampugnaro, 2015). It also discussed the dimensions of political party resources and the role of the community in party activities (Rangel, 2017), and also structural relations, resources, and functions of party representation (Scarrow et al., 2017). Scarrow added a discussion about political parties' way of life, competition between political parties, and between political actors in internal political parties along with new political actors to determine political actors who would gain long-term success in the political arena (Scarrow et al., 2017). Scarrow and Webb also found that political parties act as vehicles for personal mobilization to help them gain electoral abilities (Scarrow et al., 2017). The parties then became an instrument of personal political interest, Scarrow-Webb called it "gatekeeper" as Miettinen also underlined, to bridge the interests between party politicians and the general public (Miettinen \& Poutvaara, 2015). There is a reciprocal relationship between parties and personal actors in internal party democracy which makes political parties "top-down" under the domination of the people who held power (Scarrow et al., 2017). The institutional argument of political parties built by Scarrow-Webb opened the opportunity to more specific discussion on the 
organization of political parties, that political parties have their ways to organize themselves specifically and conditionally both internally, externally, culturally and structurally (Scarrow et al., 2017) to open participation with elements and organizations outside the party (Wang, 2020).

Those scholars seem to agree on the idea of "interaction of the interests of actors" in political parties so that the discussion on the organization of political parties then develops on the discussion of inter-relationship between actors in political parties. Janda, Colman, and Scarrow saw the interrelationship between the interests of these actors present internally and externally with complex procedures, to trigger conflicts of interest between political actors, make factionalization and coalition within the party (Janda et al., 2010; Scarrow et al., 2017). By this assumption, parties' function shifted to be a gatekeeper of the interaction of interests and competition of personal actors (Close \& Sierens, 2017). They also welcomed those who wanted to pursue political nomination through their party (Cheibub \& Sin, 2015) and recruit strong people who can be a source of electoral power for them (Scarrow et al., 2017). In the internal dynamics of political parties, powerful individuals emerge, for example with charismatic powers that exert a strong influence on the party (Fionna, 2016; Singh, 2016), including outside parties that influence political party organization, for example, business players in the arena of contestation by political party leaders (Reuter, 2015). The role and competition of personal actors in political parties can also be found in the writings of Fionna-Tomsa (Fionna \& Tomsa, 2017), personal actors' appeal for political parties (Soare, 2017) so that personal politics becomes a new choice for contemporary politics dealing with the institutional role of political parties (Calise, 2015). The role of these personal actors with various backgrounds of interests (Ladkin \& Probert, 2019; Ufen, 2019) in these political party institutions extends the reach of institutional work externally (Arter, 2016). This is in line with the new institutional views derived from Panebianco and Randall-Svåsand's institutional views which incorporate external elements (Calise, 2015). The struggle for existence in these institutions encourages political actors to compete with and influence each other in political party institutions (Ayan Musil \& Dikici Bilgin, 2016; Scarrow et al., 2017). Political parties are also considered as a collective unit where inter-individual coalition and elite groups struggle to reach the top position (Lane \& Preker, 2018). In discussing the internal dynamics of political parties with the "interaction of the interests of actors", the study of organizing political parties commonly used is Intra-Party Democracy (van Biezen \& Piccio, 2013; Close et al., 2017; Lehrer, 2012; Sandri \& Amjahad, 2015; Scarrow, 2005; Scarrow et al., 2017; Seeberg et al., 2018).

\subsection{Intra-Party Democracy and Power Relations among Actors}

Intra-Party Democracy contains the notion of internal dynamics of political parties that represent competition between elites in the pursuit of power in which there is democratic control over political party elites by mass community organ- 
izations (von dem Berge \& Poguntke, 2017). The involvement of outside elements of the party is important in democratic control, for example, supporters and masses of party members (Norris, 2005; Sandri \& Amjahad, 2015), which shows the party as public utilities in Biezen's view (Van Biezen, 2004) and is as inclusive as Berge's (von dem Berge \& Poguntke, 2017). Berge's inclusiveness explains the relationship between actors in the internal political process of political parties, namely how many parties are involved in the process of determining party policies, such as the selection of party candidates and the election of political party leaders. Political parties that are considered democratic in the process of determining their policies are political parties that have the most participation from their members in the internal process. There are three components of Intra-Party Democracy in Berge's view, namely programs, personnel and organizational structures which include the inclusiveness of the process of determining political party policies, selection of party leaders and selection of political party candidates and formal distribution of power within the party (von dem Berge \& Poguntke, 2017). The Berge concept has the same viewpoint as Bolin's finding that Intra-Party Democracy can be influenced by the existence of a law or party rules, the high level of public trust in political institutions, such as political parties, and the high standard of living of a country's society (Scarrow et al., 2017). This opinion affirms the previous opinion about the cohesiveness of Intra-Party Democracy written by Giannetti and Benoit (Giannetti \& Benoit, 2008) and the accountability of leaders and party members as written by Maravall who both agreed on the relationship between actors as demands for internal democracy in internal political parties (Maravall, 2007). This reinforces Bolin's argument that Intra-Party Democracy builds the relationship between organizational structure and dynamics outside the organization of political parties, which deal with members and constituents and political recruitment such as candidate selection (Scarrow et al., 2017). That is, Intra-Party Democracy brings party representation in the community (party on the ground) to parties in public office as conceived by Katz-Mair (Katz \& Mair, 1994).

In discussing the organization of political parties, Intra-Party Democracy is sufficient to explain the dynamics that occur within the internal and external institutions of political parties. But how the "interaction of the interests of the actors", both internal and external to the party, is not sufficient enough to be reached by Intra-Party Democracy. As referred to Habermas (Habermas, J translated by Regh W, 1996) that political power includes communicative power and administrative power, then in discussing the "interaction of the interests of actors" the communicative power approach can better reach the recesses of the struggle for political resources played by political actors in discursive practices among them (Jansson, 2014; Kondowe \& Ngwira, 2019).

\subsection{Discursive Institutionalism: Multi-Vector Bridging}

Discursive Institutionalism has a communicative power perspective in explaining the relationship among actors in institutional structures both internal and 
external. As recognized by the initiator, Schmidt, Discursive Institutionalism suggests the ideas and power brought by each actor in interactional relations (Carstensen \& Schmidt, 2016; Schmidt, 2008). It is no exaggeration if Schmidt called it a rich and varied perspective on the social and political reality that is more complex than the previous three theories of New Institutionalism, namely Sociological Institutionalism, Historical Institutionalism, and Rational Institutionalism. Whereas New Institutionalism itself is the next development after the old institutionalization theory (Schmidt, 2017a; Wahlström \& Sundberg, 2018). The theory of New Institutionalism comes to replace the old theory of institutionalism because the study of institutionalization in the early 20th century left many problems, such as economic conflicts came from the clash of economic interest, cultural narratives which took over in organizing electoral politics (Bell, 1998; McConnell, 2008; Reinert, 2006), are teleological, which states that the state is only "destined to continue to grow and protect itself from competing influences" (McConnell, 2006). The New Institutionalization theory, and so does Discursive Institutionalism, which offers behavioral and post-behavioral approaches since the 1970s is functionalistic and emphasizes the functions that must be fulfilled by an institution. The basic argument of this newest institutionalization theory in the description above is on the dynamics of functional institutions, collective action, which involves multi-actors and multi-direction, that we called "multi-vector"; in its social-political relations previous institutionalism theories which emphasized aspects of social change, development and macroevolutionary considerations of various institutions but lacked emphasis on individual influences (Hadler, 2015). The dynamic character of the relational in this new institutionalization is in line with Goodin's emphasis on the new institutionalization which according to him is no longer limited to the meaning of the organization, but more than that, which refers to stable and permanent behavior, focusing on values and power relations on the interaction between institutions and individuals, no longer talk about the impact of institutions on individuals (Koning, 2016). This approach conceptualizes institutions, not as structures or cultures or passive backgrounds where social relations occur, however, institutions are causal variables that structure opportunities and constraints faced by individual and collective players, thus emphasizing the pattern of activities of political players (Negm, 2015). Here, there is a reciprocal relationship between individuals and institutions with an emphasis on individual freedom as Hayek views (Miljkovic, 2018). The idea of collective action then received attention on discursive institutionalism as a rational discourse of collectivism ( $\mathrm{Li}$ et al., 2019).

\subsection{Ideational, Collective Action and Institution}

Discursive Institutionalism focuses on the development of ideas, placing ideas in specific contexts, examining the way ideas are delivered between actors or so-called Schmidt as coordinative discourse and between politicians and the gen- 
eral public called communicative discourse (Hadler, 2015). Schmidt emphasizes the idea factor or "ideational ability", as capital in discursive practices and relations that manifest in "background discursive abilities" similar to Bourdieu's habitus (Carstensen \& Schmidt, 2016) and "foreground discursive abilities" are means actions, that the "actions" have close meaning to the idea of Habermas's communicative action and both occur in argumentative practice at the center of policy, as stated by Fischer and Forester cited by Schmidt (Schmidt, 2015).

This ideational concept also contains a load of values and beliefs, all of which are carried out through discourse (Di Gregorio et al., 2017). The Theory of Discursive Institutionalism argues that the behavior of actors is greatly influenced by how the actors interpret the world around them (Ochieng et al., 2016). In the discourse of Institutional Discursive, actors, or in the term of Schmidt called "agents", are understood as sentient agents who produce and consider ideas through discursive communication interactions that lead to collective action (Schmidt, 2017a; Schmidt, 2012). Discursive interaction is the practice of communicating to whom agents state what they think, namely who states what, to whom, when, and where to state it. This is where the argumentative interaction practice occurs which usually occurs at the level of "central policy process" (Schmidt, 2015). The idea of collective action in institutions takes place argumentatively. Discursive Institutionalism treats institutions as structures that place the context in which agents think, speak, and act. Institutions are internal for actors who function as structures in organizing thoughts, words, and actions to meet with similar organizing from other agents. Then the institutional action is "background discursive ability" where agents can maintain and or change their institutions. Agents, in Discursive Institutionalism reach out to every political leader, elected leaders, political party members, policymakers, political entrepreneurs who are influencing public opinion, mass media, interest groups, public intellectuals, opinion-makers, social movements, and ordinary citizens who make conversation everyday politics (Clément \& Zhelnina, 2019; Schmidt, 2017b). This new perspective in Discursive Institutionalism opens the space for the development of political theories in a critical, post-positivist paradigm that is needed to explain the events and dynamics of contemporary politics, in a changing, dialectic, discursive society (Connaughton et al., 2017; Mozaffari, 2015; Schmidt, 2017b).

\subsection{Summary}

Organizing political parties representing a common and interlinked action consisting of competition among actors, where actors interact with each other in pursuit of their respective interests. They, party leaders, party officials, party members, election candidates, compete in complex procedures. Political party institutions, such as the melting pot where various interests meet, in which there is a reciprocal process between institutional and individual face. Party leaders also need an internal strategy to get internal party support to carry out the party's external strategy, for example building a social link for political and financial 
support, building a coalition, etc. Intra-Party Democracy represents the cohesiveness of the political process in the internal party which is loaded with many interests, many resources, power played by many actors. This multi-vector relation in Intra-Party Democracy is operationally described by Discursive Institutionalism that describing practices of ideas, concepts, and power among actors leading to collective action influencing and shaping institutions.

\section{Discussion}

\subsection{Discursive Institutionalism: Bridging Multi-Vector Power Relations}

The institutional dynamics and collective action of the argumentative-discursive ideational relations in multi-vector as explained above, are approached by two explanatory tools of Discursive Institutionalism, namely "agent's background ability" and "agent's foreground ability". Both of these explanatory tools are used by agents or actors in interacting with other actors in "communicative discourse" and "coordinative discourse". These discursive interactions occur in two types, namely "coordinative discourse", namely discursive interactions that occur among agents at the "center of the institution"; and "communicative discourse", which occurs between agents and the public at the same time on an ongoing basis (Schmidt, 2017b, 2017a). The agent's background ability includes the ideational ability to communicate ideas (Schmidt, 2008). While the interactive process that occurs between agents with the ability of "background" this allows agents to consciously change institutions, as real actions or "foreground capabilities". The ability of the agent's discursive foreground is aligned with the notion of the power of ideas that Bourdieu uses to go beyond doxa through interactive communication or producing his discourse. The role of intellectuals in Gramsci's hegemonic discourse exposes power in ideas that function as vehicles in domination and power (Kowal-Bourgonjon \& Jacobs, 2019). This is also used by Foucault to show the power of ideas in social movements (Armstrong, 2015) and the production of meaning which is an interplay between power and discourse (Latorre \& Malo-Larrea, 2019).

Communicative discourse among actors occurs in deliberative, argumentative, ideational, bargaining processes in political space. This discursive interaction is characterized by "coordinative discourse", which is the process of discursive communication that takes place among actors in the "institutional center", which is involved in the process of creating, negotiating, debating, bargaining, and reaching agreement and political domains marked by "communicative discourse" namely discursive interactions that occur between political actors and the public. Agents in "coordinative discourse" refer to actors involved in the policy process, organizing themselves in various groups as "discursive communities" to influence others. This discursive community is a "discourse coalition", conducting discourse interactions or "discursive interactions" that produce discursive reality. Discursive groups can build new social ideas or new narratives 
through this process. Coordinative discourse and communicative discourse occur at a limited elite level dealing with actors outside formal institutions (Schmidt, 2015). This discursive process can form a discursive institution, and this process occurs every time because of the coordinative discourse and communicative discourse occurs at any time. Therefore, he explained institutional change and continuity more dynamically and adaptively to social changes and political dynamics, by changing public epistemology (Brandmayr, 2019). This is what distinguishes it from the previous three institutionalism namely sociological institutionalism, historical institutionalism, and rational institutionalism in terms of institutional meaning, institutional change, interests, uncertainty, norms, and relativism (Schmidt, 2017b; Schmidt, 2015). Discursive Institutionalism explains the changes that are implied by the ideas and actions of political actors, namely through a discursive process: who states what, to whom, when, and how (Carstensen \& Schmidt, 2016; Schmidt, 2008, 2017a). The discursive process is mediated by the work of "discourse" which in the sense of Discursive Institutionalism is a whole process of organizing ideas carried out by various parties or agents in different fields. The discourse reaches out about "who states what" in the process of policy construction and political communication in the public space.

This discursive process leads to institutional changes, social-political behavior, and mobilization (Carstensen \& Schmidt, 2016). In Discursive Institutionalism, institutions are considered as a discursive process of ideas and power between actors where actors create and maintain institutions (Hadler, 2015). Discursive Institutionalism uses discourse as an agent communication act in an interactive process involving political actors, namely the process of coordinative, communicative, deliberation, contestation, and legitimization. The institution then becomes no longer material because it consists of a meeting of the actors or agents who think and speak or Schmidt calls it "sentient agents" (Schmidt, 2017b). Discursive action occurs at the "policy center on the institution", which is not necessarily the case on the "center of formal institutions", but can occur at the "point of political resources" outside the formal institutions of political parties which are not always physical, but "something of real strength", an external force that breaks through institutions (Akong, 2019). It is a virtual power relation which is also the object of the study of Discursive Institutionalism which Schmidt embraces in "discursive practices" which leads to collective action. This rationale can explain the post-truth phenomenon when political actors produce distorted information (Temmerman et al., 2019), is in harmony with Foucault's power and knowledge, namely the production of discourse to build "new knowledge" to enter its power network (Harris \& Adams, 2016).

\subsection{Discursive Institutionalism in Organizing Political Parties}

Operating Discursive Institutionalism in the study of organizing political parties is to understand the multi-vector power relations namely multi-actor, mul- 
ti-directional and multi-political resources. This power relation is explained through two explanatory tools of Discursive Institutionalism namely "agent's background ability" and "agent's foreground capability", both working in the "coordinative discourse" and "communicative discourse" corridors, depending on the context in which the discursive event occurs. Coordinative discourse takes place among elites, involving "the agent's background ability" and "agent foreground" in the discursive process between them. Communicative discourse, which takes place between the elite and the public, involves the "agent background ability" and the "agent foreground" in the discursive process between the elite and the public. In the terminology of Discursive Institutionalism, as the description above, "the ability of the background agent" is a subjective modality or actor's habitus including ideas, thoughts, knowledge, actor power used in interacting-discursive. Whereas "agent's foreground capabilities" are the real actions of agents in discursive interactions. Ideas also include the interests and powers that are manifested in these interactive relations. An institution is an aggregation of ideas, thoughts, and collective actions of the actors or agents. In political party institutions, there are discursive groups in the form of factions in party management, members, sympathizers or supporters, party wing organizations or groups, or social-based supporting parties.

Intra-Party Democracy, there was an interactive relationship among actors that was occurred both internally within political party institutions among party elites, between members and party leaders, or between party leaders and actors outside the party. Two sets of explanatory tools of Discursive Institutionalism explain the interrelation between political party actors. The dominant power in political parties is the "point of political resources" which can be inside or outside the institutions of political parties which are not always physical, but "something real virtual power", can be an external force that breaks through institutions. In the context of political parties, the discursive process of various discursive actions runs like what is called the struggle for legitimacy through the aggregation of discursive abilities by discursive groups. From the perspective of Discursive Institutionalism, the struggle for legitimacy is socially constructed from social practices carried out by constituents who react differently (Peda \& Vinnari, 2019). The complexity of the role of actors and interests between actors in political parties as explained by Intra-Party Democracy gets an additional explanation of how relations between actors that run inclusive in matters related to party policy and attraction of interest within it which is also related to elements of external forces and plural communities for broader public legitimacy (Thévenot, 2019).

\subsection{Summary}

Discursive Institutionalism bridges the discursive practices of the political actors who each carry ideas, concepts, power, as ideational concepts called "background capacity" to be brought into the arena of competition among them as 
"foreground capacity". This discursive practice occurs between political actors within internal political parties, called "coordinative discourse" and externally between actors and the public, called "communicative discourse". Intra-Party Democracy which describes the internal dynamics of political parties is related to external elements of the party, social relations, and practices loaded a consequence to party legitimacy in which the interaction process is intertwined discursively.

The findings of this research are, firstly, the complexity of the process, and institutional elements in the organization of political parties that occur discursively. Secondly, the organization of political parties is full of discursive multi-vector sources of power that are from many actors and many directions. Thirdly, the process of Intra-Party Democracy is interwoven discursively, that externally ran as discursive communities, explained by Discursive Institutionalism, which we named "Discursive Intra-Party Democracy" or "Discursive IPD". Fourthly, by this framework of analysis, the institution is analyzed as an aggregation of sentient agents of political actors whose idea and power, namely discursive institutions.

\section{Conclusion}

Discursive Institutionalism provides a more dynamic understanding of institutionalism in organizing political parties. It aims power relations in intra-party democracy that occur in a namely multi-actor, multi-directional, multi-political resources that we called it "multi-vector". The multi-vector discursive interaction process is bridged through the concepts of coordinative discourse and communicative discourse, using the "agent's background abilities" and the "agent's foreground abilities" used by the agent in communicating their ideas and power. The meaning of institutions also extends from structural physical constraints as understood by other institutionalism, to an understanding that is no longer material, that is, ideational because it consists of an aggregation of thinking-and-talking agents (sentient agents) in a wider and more complex public space. In the perspective of Discursive Institutionalism, institutions were seen as an aggregation of ideas and thoughts, represented by sentient agents or actors through a discursive process. Coordinative discourse occurs between political actors, as well as between discursive communities and/or public to gain public legitimacy.

Theoretical implications of Discursive Institutionalism or Discursive IPD in organizing political parties open broader horizons of political thought to the study of the development of political parties, electoral sources of political parties, management of political parties, political mobilization, political party competition, political campaigns and broader political communication in harmony with contemporary political episteme. Furthermore, the theoretical implications of Discursive Institutionalism are also compatible to explain the processes, dynamics, and development of political and social institutions in general as long as 
there are related actors and public spaces.

\section{Acknowledgements}

This article uses a literature review research method, so it does not require human involvement as research participants. There were no conflicts of interest before, during, and after conducting a literature review research, writing, and completion of this article. Therefore, the right to declare approval of the publication of this manuscript is with us as the author(s), and we agree that this article is for publication.

\section{Conflicts of Interest}

The authors declare no conflicts of interest regarding the publication of this paper.

\section{References}

Akong, C. (2019). Reframing Matter: Towards a Material-Discursive Framework for Africa's Minerals. Extractive Industries and Society, 7, 461-469. https://doi.org/10.1016/j.exis.2019.02.007

Armstrong, P. (2015). The Discourse of Michel Foucault: A Sociological Encounter. Critical Perspectives on Accounting, 27, 29-42. https://doi.org/10.1016/j.cpa.2013.10.009

Arter, D. (2016). When New Party X Has the "X Factor": On Resilient Entrepreneurial Parties. Party Politics, 22, 15-26. https://doi.org/10.1177/1354068813509523

Ayan Musil, P., \& Dikici Bilgin, H. (2016). Types of Outcomes in Factional Rivalries: Lessons from Non-Democratic Parties in Turkey. International Political Science Review, 37, 166-183. https://doi.org/10.1177/0192512114539982

Bell, S. (1998). Institutionalism: Old and New (pp. 1-16).

Brandmayr, F. (2019). Public Epistemologies and Intellectual Interventions in Contemporary Italy. International Journal of Politics, Culture and Society. https://doi.org/10.1007/s10767-019-09346-3

Burgers, C., Brugman, B. C., \& Boeynaems, A. (2019). Systematic Literature Reviews: Four Applications for Interdisciplinary Research. Journal of Pragmatics, 145, 102-109. https://doi.org/10.1016/j.pragma.2019.04.004

Calise, M. (2015). The Personal Party: An Analytical Framework. Rivista Italiana Di Scienza Politica, 45, 301-315. https://doi.org/10.1017/ipo.2015.18

Carstensen, M. B., \& Schmidt, V. A. (2016). Power through, over and in Ideas: Conceptualizing Ideational Power in Discursive Institutionalism. Journal of European Public Policy, 23, 318-337. https://doi.org/10.1080/13501763.2015.1115534

Cheibub, J. A., \& Sin, G. (2015). Order in Chaos Intra Party Coordination in Open List PR Systems. In 72nd Annual Midwest Political Science Association Conference (pp. $1-18)$.

http://publish.illinois.edu/giselasin/files/2014/08/Order-in-Chaos-Intra-Party-Coordin ation-in-Open-List-Proportional-Representation-Systems.pdf

Clément, K., \& Zhelnina, A. (2019). Beyond Loyalty and Dissent: Pragmatic Everyday Politics in Contemporary Russia. International Journal of Politics, Culture and Society. https://doi.org/10.1007/s10767-019-9319-0

Close, C., \& Sierens, V. (2017). Increasing Intra-Party Democracy, Blurring the Lines of 
Representation.

Close, C., Kelbel, C., \& van Haute, E. (2017). What Citizens Want in Terms of Intra-Party Democracy: Popular Attitudes towards Alternative Candidate Selection Procedures. Political Studies, 65, 646-664. https://doi.org/10.1177/0032321716679424

Connaughton, S. L., Linabary, J. R., \& Yakova, L. (2017). Discursive Construction. In The International Encyclopedia of Organizational Communication (Vol. 1, pp. 1-13). Hoboken, NJ: John Wiley \& Sons. https://doi.org/10.1002/9781118955567.wbieoc063

Dalton, R. J., Wattenberg, M. P., Farrell, D. M., \& Webb, P. (2003). Political Parties as Campaign Organizations. In R. J. Dalton, \& M. P. Wattenberg (Eds.), Parties without Partisans: Political Change in Advanced Industrial Democracies (pp. 102-126). Oxford: Oxford University Press. https://doi.org/10.1093/0199253099.003.0006

Di Gregorio, M., Gallemore, C. T., Brockhaus, M., Fatorelli, L., \& Muharrom, E. (2017). How Institutions and Beliefs Affect Environmental Discourse: Evidence from an Eight-Country Survey on REDD+. Global Environmental Change, 45, 133-150. https://doi.org/10.1016/j.gloenvcha.2017.05.006

Emanuele, V., \& Marino, B. (2016). Follow the Candidates, Not the Parties? Personal Vote in a Regional De-Institutionalized Party System. Regional and Federal Studies, 26, 531-554. https://doi.org/10.1080/13597566.2016.1226812

Emanuele, V., Carli, L. G., Universit, L., Sociali, S., Yield, I., \& View, W. E. (2015). From a Party System to a Candidate System? Lords of Preferences and Electoral Support in Calabria.

Fionna, B. U., \& Tomsa, D. (2017). Parties and Factions in Indonesia: The Effects of Historical Legacies and Institutional Engineering (pp. 1-27).

Fionna, U. (2016). Indonesian Parties in a Deep Dilemma: The Case of Golkar Introduction: New Leadership Controversy (No. 35, pp. 1-7). https://www.iseas.edu.sg/images/pdf/ISEAS_Perspective_2016_35.pdf

Garzia, D. (2013). The Rise of Party/Leader Identification in Western Europe. Political Research Quarterly, 66, 533-544. https://doi.org/10.1177/1065912912463122

Gentles, S. J., Charles, C., Nicholas, D. B., Ploeg, J., \& McKibbon, K. A. (2016). Reviewing the Research Methods Literature: Principles and Strategies Illustrated by a Systematic Overview of Sampling in Qualitative Research. Systematic Reviews, 5, 172. https://doi.org/10.1186/s13643-016-0343-0

Giannetti, D., \& Benoit, K. (2008). Intra-Party Politics and Coalition Governments. London: Routledge. https://doi.org/10.4324/9780203889220

Guizzo, D., \& de Lima, I. V. (2015). Foucault's Contributions for Understanding Power Relations in British Classical Political Economy. Economia, 16, 194-205. https://doi.org/10.1016/j.econ.2015.06.002

Gunther, R., \& Diamond, L. (2003). Species of Political Parties: A New Typology. Party Politics, 9, 167-199. https://doi.org/10.1177/13540688030092003

Habermas, J. (1996). Contributions to a Discourse Theory of Law and Democracy Jurgen Habermas (Translated by Regh, W.).

Hadler, M. (2015). Institutionalism and Neo-Institutionalism: History of the Concepts. In International Encyclopedia of the Social \& Behavioral Sciences (2nd ed., Vol. 12). Amsterdam: Elsevier. https://doi.org/10.1016/B978-0-08-097086-8.03187-1

Harris, K., \& Adams, A. (2016). Power and Discourse in the Politics of Evidence in Sport for Development. Sport Management Review, 19, 97-106.

https://doi.org/10.1016/j.smr.2015.05.001

Hofvenschioeld, E., \& Khodadadi, M. (2020). Communication in Futures Studies: A Dis- 
cursive Analysis of the Literature. Futures, 115, Article ID: 102493.

https://doi.org/10.1016/j.futures.2019.102493

Huntington, S. P., \& Fukuyama, F. (2006). Political Order in Changing Societies.

Hurlbert, M. A., \& Gupta, J. (2019). An Institutional Analysis Method for Identifying Policy Instruments Facilitating the Adaptive Governance of Drought. Environmental Science and Policy, 93, 221-231. https://doi.org/10.1016/j.envsci.2018.09.017

Hutzschenreuter, T., Matt, T., \& Kleindienst, I. (2020). Going Subnational: A Literature Review and Research Agenda. Journal of World Business, 55, Article ID: 101076. https://doi.org/10.1016/j.jwb.2020.101076

Janda, K., \& Colman, T. (1998). Effects of Party Organization on Performance during the “Golden Age" of Parties. Political Studies, 46, 611-632. https://doi.org/10.1111/1467-9248.00157

Janda, K., Kwak, J., \& Suarez-cao, J. (2010). Party System Effects on Country Governance. Review Literature and Arts of the Americas, 11, 423-446.

Jansson, N. (2014). Discursive Practices in Organizational Change. http://herkules.oulu.fi/isbn9789526205229/isbn9789526205229.pdf

Katz, R. S., \& Mair, P. (1994). How Parties Organize: Change and Adaptation in Party Organizations in... 375. http://books.google.com/books?hl=en\&lr=\&id=-Lq20h5xJrUC\&pgis=1

Katz, R. S., \& Mair, P. (1995). Changing Models of Party Organization and Party Democracy: The Emergence of the Cartel Party. Party Politics, 1, 5-28. https://doi.org/10.1177/1354068895001001001

Katz, R. S., Mair, P., Haid, C. J., Press, C., Borz, G., \& Janda, K. (2008). The Three Faces of Party Organization. Political Science, 46, 593-617.

Kondowe, W., \& Ngwira, F. F. (2019). Projecting Voice in Political Discourse: A Study of Saulos Klaus Chilima's Discursive Strategies, Malawi. Theory and Practice in Language Studies, 9, 500. https://doi.org/10.17507/tpls.0905.03

Koning, E. A. (2016). The Three Institutionalisms and Institutional Dynamics: Understanding Endogenous and Exogenous Change. Journal of Public Policy, 36, 639-664. https://doi.org/10.1017/S0143814X15000240

Kowal-Bourgonjon, E., \& Jacobs, G. (2019). Does Addiction belong in Modernity? Discursive Strategies of Exclusion in Polish Public Awareness Campaigns. Discourse, Context and Media, 28, 27-34. https://doi.org/10.1016/j.dcm.2019.01.004

Ladkin, D., \& Probert, J. (2019). From Sovereign to Subject: Applying Foucault's Conceptualization of Power to Leading and Studying Power within Leadership. Leadership Quarterly, Article ID: 101310. https://doi.org/10.1016/j.leaqua.2019.101310

Lane, J.-E., \& Preker, A. M. (2018). Political Parties, Coalitions and Democracy. Open Journal of Political Science, 8, 447-466. https://doi.org/10.4236/ojps.2018.84029

Language, S., Program, E., Wang, H., \& Services, L. (2018). The Palgrave Handbook of Applied Linguistics Research Methodology (pp. 123-144). London: Palgrave Macmillan.

Larsson, O. L. (2015). Using Post-Structuralism to Explore the Full Impact of Ideas on Politics. Critical Review, 27, 174-197. https://doi.org/10.1080/08913811.2015.1073883

Latorre, S., \& Malo-Larrea, A. (2019). Policy-Making Related Actors' Understandings about Nature-Society Relationship: Beyond Modern Ontologies? The Case of Cuenca, Ecuador. Ecological Economics, 156, 387-396. https://doi.org/10.1016/j.ecolecon.2018.10.017

Lehrer, R. (2012). Intra-Party Democracy and Party Responsiveness. West European Pol- 
itics, 35, 1295-1319. https://doi.org/10.1080/01402382.2012.713747

Lehrer, R. (2016). Intra-Party Democracy and Coalition Survival.

Li, F., Liu, Y., \& Meng, T. (2019). Discursive Strategy of Opinion Expression and Government Response in China: Text Analysis Based on Online Petitions. Telematics and Informatics, 42, Article ID: 101238. https://doi.org/10.1016/j.tele.2019.06.001

Mair, P., Katz, R. S., Kolodny, R., Muller, W. C., Deschouwer, K., Webb, P. D., Bille, L., Sundberg, J., \& Poguntke, T. (2020). Contributors Preface and Acknowledgements 1 Party Organizations: From Civil Society to the State (pp. 10-11).

Maravall, J. M. (2007). The Political Consequences of Internal Party Democracy. In Controlling Governments: Voters, Institutions, and Accountability (pp. 157-201). Cambridge: Cambridge University Press. https://doi.org/10.1017/CBO9780511611414.008

McConnell, S. (2008). The Old Institutionalism and the New. Polity, 40, 326-331. https://doi.org/10.1057/pol.2008.5

McConnell, S. A. (2006). The Financing of Politics: Latin American and European Perspectives (Review). Latin American Politics \& Society, 48, 199-203. https://doi.org/10.1353/lap.2006.0035

Meeks, L. (2017). Getting Personal: Effects of Twitter Personalization on Candidate Evaluations. Politics and Gender, 13, 1-25. https://doi.org/10.1017/S1743923X16000696

Miettinen, T., \& Poutvaara, P. (2015). Parties as Efficiency-Improving Gatekeepers in Rent-Seeking Societies. European Journal of Political Economy, 38, 87-101. https://doi.org/10.1016/j.ejpoleco.2015.01.003

Mikola, B. (2017). Online Primaries and Intra-Party Democracy: Candidate Selection Processes in Podemos and the Five Star Movement. IDP Revista de Internet, Derecho $y$ Política, No. 24, 37-49. https://doi.org/10.7238/idp.v0i24.3070

Miljkovic, D. (2018). The Relationship between Individual and Institutional Freedom. Open Journal of Political Science, 8, 81-94. https://doi.org/10.4236/ojps.2018.82007

Mozaffari, A. (2015). Construction of Reality and Naturalization of Ideology through the Discourse of Cinema: A Critical Discourse Analysis of a Separation. Journal of Socialomics, 5, 138. https://doi.org/10.4172/2167-0358.1000138

Negm, M. S. (2015). Resisting Power in Discourse. Procedia-Social and Behavioral Sciences, 192, 284-289. https://doi.org/10.1016/j.sbspro.2015.06.041

Norris, P. (2005). Building Political Parties: Reforming Legal Regulations and Internal Rules. Building, 1-59.

Ochieng, R. M., Visseren-Hamakers, I. J., Brockhaus, M., Kowler, L. F., Herold, M., \& Arts, B. (2016). Historical Development of Institutional Arrangements for Forest Monitoring and REDD + MRV in Peru: Discursive-Institutionalist Perspectives. Forest Policy and Economics, 71, 52-59. https://doi.org/10.1016/j.forpol.2016.07.007

Peda, P., \& Vinnari, E. (2019). The Discursive Legitimation of Profit in Public-Private Service Delivery. Critical Perspectives on Accounting, 69, Article ID: 102088. https://doi.org/10.1016/j.cpa.2019.06.002

Poguntke, T. (2002). Party Organizational Linkage: Parties without Firm Social Roots? In K. R. Luther, \& F. Muller-Rommel (Eds.), Political Parties in the New Europe: Political and Analytical Challenges (pp. 43-62). Oxford: Oxford University Press.

Rahat, G., \& Hazan, R. Y. (2013). Increased Personalisation in an Unstable Party System: The 2013 Elections in Israel. Representation, 49, 375-389.

https://doi.org/10.1080/00344893.2013.830477

Randall, V., \& Svåsand, L. (2002). Party Institutionalization in New Democracies. Party Politics, 8, 5-26. https://doi.org/10.1177/1354068802008001001 
Rangel, G. S. (2017). Voting as a (Mandatory) Duty: Citizen Attitudes, Political Engagement, and Party Outreach under Compulsory Voting (p. 208). ProQuest Dissertations and Theses.

http://ezphost.dur.ac.uk/login?url=https://search.proquest.com/docview/1937500377?a ccoun-

tid=14533\%0Ahttp://openurl.ac.uk/ukfed:dur.ac.uk?genre=dissertations+\%26+theses\& issn $=\&$ title $=$ Voting + as $+\mathrm{a}+\% 28 \mathrm{Mandatory} \% 29+\mathrm{Duty} \% 3 \mathrm{~A}+\mathrm{Citizen}+$ Attitudes $\% 2 \mathrm{C}+\mathrm{Pol}$ itical+Engageme

Reinert, E. S. (2006). Institutionalism Ancient, Old and New. A Historical Perspective on Institutions and Uneven Development. Research P 27, A0719.

Reuter, T. (2015). Political Parties and the Power of Money in Indonesia and Beyond. TRaNS: Trans-Regional and-National Studies of Southeast Asia, 3, 267-288. https://doi.org/10.1017/trn.2014.23

Sampugnaro, R. (2015). The Differentiation of Parties through the Lens of an Electoral Campaign: Planning and Implementation of Knockthevote in a European Election (Pes, 2014). Partecipazione e Conflitto, 8, 140-166.

Sandri, G., \& Amjahad, A. (2015). Party Membership and Intra-Party Democracy: How Do Members React to Organizational Change within Political Parties? The Case of Belgium. Partecipazione e Conflitto, 8, 190-214.

Scarrow, S. E. (2005). Implementing Intra-Party Democracy. In Political Parties and Democracy in Theoretical and Practical Perspectives (p. 22). Washington DC: The National Democratic Institute for International Affairs (NDI).

Scarrow, S. E., Webb, P. D., \& Poguntke, T. (2017). Organizing Political Parties: Representation, Participation, and Power (p. 362). Oxford: Oxford University Press. https://doi.org/10.1093/oso/9780198758631.001.0001

Schmidt, V. A. (2008). Discursive Institutionalism: The Explanatory Power of Ideas and Discourse. Annual Review of Political Science, 11, 303-326. https://doi.org/10.1146/annurev.polisci.11.060606.135342

Schmidt, V. A. (2010). Analyzing Ideas and Tracing Discursive Interactions in Institutional Change: From Historical Institutionalism to Discursive Institutionalism. In Presentation for the Panel: "Ideas, Power and Public Policy" at the Annual Meetings of the American Political Science Association (p. 28).

https://papers.ssrn.com/sol3/papers.cfm?abstract_id=1642947

Schmidt, V. A. (2012). Discursive Institutionalism: Scope, Dynamics, and Philosophical Underpinnings. In The Argumentative Turn Revised: Public Policy as Communicative Practice (pp. 85-113). Durham, NC: Duke University Press. https://doi.org/10.1215/9780822395362-004

Schmidt, V. A. (2015). Discursive Institutionalism: Understanding Policy in Context. In F. Fischer, D. Torgerson, A. Durnová, \& M. Orsini (Eds.), Handbook of Critical Policy Studies (pp. 171-189). Cheltenham: Edward Elgar Publishing. https://doi.org/10.4337/9781783472352.00016

Schmidt, V. A. (2017a). Britain-Out and Trump-In: A Discursive Institutionalist Analysis of the British Referendum on the EU and the US Presidential Election. Review of International Political Economy, 24, 248-269. https://doi.org/10.1080/09692290.2017.1304974

Schmidt, V. A. (2017b). Theorizing Ideas and Discourse in Political Science: Intersubjectivity, Neo-Institutionalisms, and the Power of Ideas. Critical Review, 29, 248-263. https://doi.org/10.1080/08913811.2017.1366665

Seeberg, M. B., Wahman, M., \& Skaaning, S. E. (2018). Candidate Nomination, In- 
tra-Party Democracy, and Election Violence in Africa. Democratization, 25, 959-977. https://doi.org/10.1080/13510347.2017.1420057

Serpa, S., \& Ferreira, C. M. (2019). Micro, Meso and Macro Levels of Social Analysis. International Journal of Social Science Studies, 7, 120. https://doi.org/10.11114/ijsss.v7i3.4223

Shin, J. H. (2017). The Choice of Candidate-Centered Electoral Systems in New Democracies. Party Politics, 23, 160-171. https://doi.org/10.1177/1354068815581539

Singh, S. (2016). Political Field Dynamics and the Elite's Interest in Democracy: Insights from the Political Elite's Role in Consolidating Indian Democracy. International Journal of Politics, Culture and Society, 29, 183-208. https://doi.org/10.1007/s10767-015-9211-5

Snyder, H. (2019). Literature Review as a Research Methodology: An Overview and Guidelines. Journal of Business Research, 104, 333-339. https://doi.org/10.1016/j.jbusres.2019.07.039

Soare, S. (2017). Populism and Leadership: Is There Anything New under the Sun? Studia Universitatis Babes-Bolyai Sociologia, 62, 121-149. https://doi.org/10.24193/subbeuropaea.2017.3.06

Susewind, R. (2020). Rifah-e Aam Club, Lucknow: Public Sphere and Public Space in Urban India. Geoforum, 109, 67-77. https://doi.org/10.1016/j.geoforum.2020.01.012

Tan, P. J. (2006). Indonesia Seven Years after Soeharto: Party System Institutionalization in a New Democracy. Contemporary Southeast Asia, 28, 88-114.

https://doi.org/10.1355/CS28-1E

Temmerman, M., Moernaut, R., Coesemans, R., \& Mast, J. (2019). Post-Truth and the Political: Constructions and Distortions in Representing Political Facts. Discourse, Context and Media, 27, 1-6. https://doi.org/10.1016/j.dcm.2018.10.002

Thévenot, L. (2019). How Does Politics Take Closeness into Account? Returns from Russia. International Journal of Politics, Culture and Society. https://doi.org/10.1007/s10767-019-9322-5

Torcal, M., \& Mainwaring, S. (2003). The Political Re-Crafting of Social Bases of Political Competition. British Journal of Political Science, 33, 54-84. https://doi.org/10.1017/S0007123403000036

Ufen, A. (2019). Participation without Democracy. Containing Conflict in Southeast Asia, by Garry Rodan. Democratization, 26, 346-348. https://doi.org/10.1080/13510347.2018.1512971

Van Biezen, I. (2004). Political Parties as Public Utilities. Party Politics, 10, 701-722. https://doi.org/10.1177/1354068804046914

van Biezen, I., \& Piccio, D. R. (2013). Shaping Intra-Party Democracy: On the Legal Regulation of Internal Party Organizations. In W. P. Cross, \& R. S. Katz (Eds.), The Challenges of Intra-Party Democracy (pp. 27-48). Oxford: Oxford University Press. https://doi.org/10.1093/acprof:oso/9780199661879.003.0003

Van Gorp, J. A. A. M., Garcé, A., \& Schmidt, V. A. (2011). Ideas and the Study of Political Parties: The Added Value of the Discursive Institutionalist Approach. Revista Uruguaya de Ciencia Política, 24, 2.

Vernardakis, C. (2012). From Mass Parties to Cartel Parties: The Evolution of the Structure of Political Parties in Greece through Changes in Their Statutes and Systems of Financing (pp. 1-23).

von dem Berge, B., \& Poguntke, T. (2017). Varieties of Intra-Party Democracy: Conceptualization and Index Construction. In Organizing Political Parties: Representation, 
Participation, and Power (pp. 136-157). Oxford: Oxford University Press. https://doi.org/10.1093/oso/9780198758631.003.0006

Wahlström, N., \& Sundberg, D. (2018). Discursive Institutionalism: Towards a Framework for Analysing the Relation between Policy and Curriculum. Journal of Education Policy, 33, 163-183. https://doi.org/10.1080/02680939.2017.1344879

Wang, Y. (2020). The Influence of Party Organization's Participation in External Governance on the Innovation of China's State-Owned Enterprises. Open Journal of Political Science, 10, 347-362. https://doi.org/10.4236/ojps.2020.102022

Webb, P., \& White, S. (2007). Party Politics in New Democracies (pp. 1-400). Oxford: Oxford University Press. https://doi.org/10.1093/acprof:oso/9780199289653.001.0001

Webb, P., \& White, S. (2008). Political Parties in New Democracies (pp. 345-370). Oxford: Oxford University Press.

https://doi.org/10.1093/acprof:oso/9780199289653.003.0012 